\title{
Přínos badatelsky orientovaného vyučování (BOV) pro environmentální výchovu: Př́ípadová studie implementace BOV do výuky na Zš
}

\author{
Renata Ryplová, Jarmila Reháková \\ Envigogika 2011/VI/3- Recenzované články/ Reviewed Papers \\ Publikováno/Published 31. 12. 2011 \\ DOI: http://dx.doi.org/10.14712/18023061.65
}

\begin{abstract}
Abstrakt:
Článek přináší výsledky pedagogického výzkumu analyzujícího implementaci tzv. badatelsky orientované výuky (BOV) do environmentální výchovy žáků ZŠ na príkladu tématu "Strom: Funkce v krajině a význam pro člověka". Na principech BOV byl sestaven výukový program pro interaktivní tabuli, který byl ověřován $v 7$. tř́dách ZŠ. Následným didaktickým testem byl zjištěn pozitivní vliv aplikované BOV na stupeň znalostí v oblasti environmentální výchovy u testovaných žáků. BOV s využitím interaktivní tabule byla žáky velmi pozitivně přijímána a podnítila zájem o probíranou tématiku. Článek dále přináší stručnou charakteristiku a vymezení pojmu BOV, dále diskutuje př́nos BOV pro environmentální výchovu a nastiňuje možnosti uplatnění BOV v tomto oboru.
\end{abstract}

\section{Klíčová slova:}

Badatelsky orientované vyučování v přírodních vědách (BOVB), environmentální výchova, interaktivní tabule

\begin{abstract}
:
This article brings the results of the research analysing an implementation of the Inquiry based science education into environmental education of the pupils at basic school. The results of the case study using the topic "The tree: The function in the landscape and the significance for the people" are shown. An educational programme for interactive whiteboard was composed according to IBSE rules and applied in the education of the 7 th class of the basic school. Following didactic test proved the positive influence of IBSE on the level of the environmental knowledge of the tested pupils. IBSE using interactive whiteboard was accepted very positively by basic school pupils and increased their interest on the topic of the education during the lesson. The article further brings a short characteristic of the IBSE and discusses its contribution for environmental education as well as further possibilities for the use of IBSE in this area of education.
\end{abstract}

\section{Key words:} whiteboard

Inquiry based science education (IBSE), environmental education, interactive 
Přírodovědné vzdělání nejen v Čechách, ale i v Evropě prochází v současné době krizí, která se projevuje především poklesem zájmu mládeže o přírodovědné obory. Vzhledem $\mathrm{k}$ těsnému spojení mezi přírodovědnými disciplinami a environmentální problematikou se pak pokles zájmu u dětí a mládeže samozřejmě projevuje i v této oblasti, což je z hlediska celospolečenského vývoje velmi znepokojivé. Podle výsledků průzkumu PISA (OECD Programme for International Student Assessment) jsou čeští žáci neúspěšní v rozpoznávání prrírodovědných otázek (Czesaná a kol., 2009). Z toho Ize tedy usuzovat i na malou míru jejich environmentální senzitivity. Podle závěrů expertní skupiny Evropské komise (European Commission, 2007) je hlavní příčinou této krize ve vzdělání zpưsob výuky přírodovědných předmětů. Stávající převážně deduktivní způsob výuky je pro žáky neatraktivní. Také ze závěrů hloubkové studie aktuálního stavu přírodovědného vzdělávání v Evropě zpracované Osbornem a Dillonem (2008) vyplývá, že závažnost prírodovědeckého vzdělávání v zemích EU je podceňována, a to především ve smyslu jejího významu pro každodenní život. Autoři této studie dále zdůrazňují nutnost takové změny kurikula, která by posílila spojení přírodovědeckého vzdělávání s aktuálními globálními problémy lidstva, jako jsou např. globální změny klimatu, zásoby vody, produkce potravin, zdroje energie apod.), tedy jinými slovy řečeno, volají po posílení role environmentální výchovy.

Jako východisko z této situace, které splňuje výše uvedené požadavky, se jeví tzv. Badatelsky Orientované Vyučování v Biologii (BOVB - z angl. IBSE - Inquiry Based Science Education), které je již v řadě evropských zemí s úspěchem zavedeno. (např. Projekt Pollen, Program SINUS - Transfer - podrobněji viz např. Janoušková a kol., 2008). V české didaktice se termín BOVB začíná výrazněji prosazovat teprve $v$ posledních letech. Pojem badatelsky orientovaného vyučování charakterizuje např. Papáček (2010) jako jednu z účinných aktivizujících metod problémového učení, kdy učitel nepředává učivo výkladem $v$ hotové podobě, ale vytváří znalosti cestou rešení problému a systémem kladených otázek. Stuchlíková (2010) rozděluje podle Eastwella (2009) badatelsky orientované vyučování na několik typů:

- potvrzující bádání - otázka i postup jsou studentům poskytnuty, výsledky jsou známy, jde o to je vlastní praxí ověřit;

- $\quad$ strukturované bádání - otázku i možný postup sděluje učitel, studenti na tomto základě formulují vysvětlení studovaného jevu;

- nasměrované bádání - učitel dává výzkumnou otázku, studenti vytvářejí metodický postup a realizují jej;

- otevřené bádání - studenti si kladou otázku, promýšlejí postup, provádějí výzkum a formulují výsledky.

Pro využití BOV v environmentální výchově je důležité, že inspiraci pro celou řadu úvodních problémových otázek pokládaných žákưm a nutících je k zamyšlení mohou pedagogové čerpat $v$ bezprostředním okolí - v každodenním životě. Vhodnost využití BOV v environmentální výchově rozebírá např. Forbes a kol. (2011). Význam badatelsky orientovaného vyučování je zdůrazňován také ve smyslu jeho prínosu pro vzdělání pro trvale udržitelný rozvoj (Ye a kol., 2008) či řešení problémů současného světa v globálním měřítku (Michaels a kol., 2008).

Environmentální výuka na základní škole je v českém prostředí jedním z průřezových témat Rámcového vzdělávacího plánu (RVP). K naplnění jejích cílů je podle Janouškové (2005) ve výuce nutno využívat takové metody, formy a postupy práce, které jsou založené na prožitcích a zkušenostech žáků. Z tohoto pohledu se tedy badatelsky orientované vyučování umožňující využití experimentů, terénních exkurzí či laboratorních prací jeví pro environmentální výuku jako velmi vhodné. Na druhé straně však zavádění 
BOV naráží i na řadu překážek (shrnutí viz např. Edelson a kol. 1999, Papáček, 2010). Lze tedy předpokládat, že i uplatnění BOV v environmentální výchově se bude potýkat s takovými problémy, jako je např. nedostatečná vybavenost škol a slabé technické zázemí k provádění experimentů, malý časový prostor pro výuku či nedostatečná motivace učitelů ke změně zavedených stereotypů výuky.

Jedním z možných řešení této situace se jeví využití moderní interaktivní techniky ve výuce. Využití interaktivní tabule např. umožňuje $v$ relativně krátkém časovém úseku předvedení videonahrávek i složitějších experimentů, předem připravených animací využívajících např. fotodokumentaci z terénu, výukových schémat, ekologicky zaměřených her apod., to vše navíc v interaktivní formě a s využitím žáky obvykle pozitivně přijímané počítačové techniky. (Více o využití interaktivní tabule např. Hammond a kol., 2011) V tomto případě žáci sice sami aktivně nepracují přímo na provádění experimentů, mohou ale stavět své myšlenkové postupy na experimentech demonstračních, zařazených v uceleném výukovém programu. Praktická činnost žáků pak spočívá $v$ samostatném vyvození závěrů ze shlédnutých experimentů $v$ interaktivních úlohách. Vhodný výběr a logické razení použitých experimentů a environmentálně orientovaných interaktivních úloh pak vede žáky k postupnému vyřešení nastoleného problému.

Následující případová studie přináší výsledky experimentální aplikace výukového programu pro interaktivní tabuli sestaveného podle principů badatelsky orientovaného vyučování ve výuce žáků 7. tříd ZŠ. Na tomto příkladu je analyzován přínos BOV pro environmentální výchovu.

\section{Výukový program pro interaktivní tabuli}

Výukový program pro interaktivní tabuli s názvem "Strom: Funkce v krajině a význam pro člověka" byl sestaven na principu badatelsky orientovaného vyučování v rámci diplomové práce řešené na katedře biologie PF JU (Reháková, 2011). Program byl koncipován $v$ souladu $s$ Rámcovým vzdělávacím programem pro základní vzdělávání. Obsahově vychází z učiva sedmého ročníku základní školy, navazuje ale již na znalosti žáků z předcházejících ročníků. Rozsah učiva odpovídá učebnicím běžně používaným pro výuku na základních školách v sedmém a šestém ročníku. $\mathrm{V}$ tomto výukovém programu jsou základní fyziologické procesy, jako je fotosyntéza a transpirace, nazírány především z pohledu jejich dopadu na životní prostředí člověka. Program je koncipován podle tzv. strukturovaného typu badatelsky orientovaného vyučování (Eastwell, 2009), tzn. učitel (zde veden výukovým programem) usměrňuje samostatné bádání žáků, formulování hypotéz, vyvozování závěrů apod.

V úvodu programu je žákům položena základní otázka: Jaké funkce má strom v krajině?

Ve snaze zodpovědět tuto otázku žáci formulují jednotlivé hypotézy, které jsou zobrazovány na interaktivní tabuli. Další průběh programu pak vede žáky tak, aby na základě výsledků demonstračních pokusů, které jsou zařazeny do výukového programu v přesném logickém sledu ve formě videosekvencí, vyvozovali dílčí závěry, jejichž syntézou pak v závěru celého výukového programu dojdou $k$ potvrzení svých na začátku stanovených hypotéz. V průběhu programu tedy žáci neprovádějí vlastní experimenty. Hledají však odpovědi na dílčí problémové otázky, které jsou jim před každým demonstračním pokusem předkládány, a samostatně pak vyvozují závěry, které uplatňují v interaktivních úlohách, hrách a animacích navazujících na každou videosekvenci. Tím se nenásilnou formou seznamují nejen s principy fyziologických dějů (fotosyntéza, transpirace), ale především si uvědomují příčinné ekologické souvislosti mezi jevy známými $z$ běžného života a fyziologickými procesy $v$ rostlinném těle, povšimnou si mnohostranného přínosu stromů $v$ krajině pro člověka. Jsou tak vedeni $k$ uvědomování si důležitosti přírodních procesů $v$ jejich bezprostředním okolním světě a každodenním životě. 
Jako př́klad Ize uvést vysvětlení procesu transpirace rostlin: v úvodu žáci shlédnou motivační videonahrávku z prostředí rozpáleného letního města, kde lidé hledají únik před horkem ve stínu. Z této videonahrávky vyplývá problémová otázka: Proč je stín pod stromem chladnější než stín pod slunečníkem? Následuje videonahrávka demonstračních pokusů přinášejících důkazy o tom, že a) rostliny vypařují vodu, následně b) při přeměně vody na vodní páru se spotřebovává tepelná energie (přirovnáním stromu ohřívaného sluncem $\mathrm{k}$ vodě vařící se na sporáku), dále že $\mathrm{c}$ ) voda se uvolňuje listy (známý Stahlův důkaz listové transpirace pomocí chloridu kobaltnatého). Závěry ze shlédnutých pokusů žáci využijí $v$ interaktivní úloze, jejímž výsledkem je část animace toku sluneční energie $\checkmark$ krajině, která je pak doplněna učitelem, který také celou problematiku shrne a upozorní na vysvětlení fyziologického děje transpirace a jeho významu jak pro rostlinu samotnou (vedení vody, čerpání živin, hospodaření s vodou), tak i pro okolní krajinu (ochlazování okolního vzduchu). $\mathrm{K}$ pochopení procesu transpirace tak žáci docházejí jaksi "mimochodem" vyvozením závěrů z procesů probíhajících v jejich bezprostředním okolí. Současně s načerpáním poznatků z oboru fyziologie rostlin tedy zároveň dochází k posílení environmentální výchovy.

Program byl sestaven $v$ editoru SMART Notebook, ale jeho plná funkčnost je zachována i v programech Team Wiever, Q-Draw, a ACTIV studio.

\section{Metodika didaktického výzkumu}

Přínos badatelsky orientovaného vyučování pro environmentální výuku byl testován na příkladu aplikace výše zmíněného interaktivního výukového programu ve výuce žáků sedmých ročníků základních škol. Pedagogickému experimentu bylo celkem podrobeno 57 žáků ze tří různých základních škol. $V$ každé tř́ídě byli žáci zcela náhodně rozděleni na dvě poloviny (přidělením čísel dle abecedního pořadí a dále rozdělením na skupiny žáků se sudým a lichým číslem). První skupina absolvovala výuku s uplatněním výukového programu pro interaktivní tabuli sestaveného podle principů badatelsky orientovaného vyučování. Paralelně byly druhé skupině tytéž informace prezentovány formou frontální výuky bez využití principů BOV. Výuka se uskutečnila $v$ obou prípadech $v$ rámci jedné hodiny. Frontální výuka byla $v$ jednotlivých tř́́dách vedena vyučujícími prírodopisu, na které byli žáci zvyklí. Vzhledem $\mathrm{k}$ tomu, že někteř́i tito vyučující neměli dostatečné zkušenosti s použiváním interaktivní tabule, byla interaktivní badatelsky orientovaná výuka vedena ve všech třídách diplomantkou (J. Reháková, PF JU), v rámci jejíž diplomové práce používaný výukový program vznikl.

Pro porovnání úrovně znalostí obou testovaných skupin a vyloučení možnosti zkreslení výsledků studie rozdílnou mírou spontánních znalostí před absolvováním výuky absolvovali všichni žáci společně úvodní test (dále test č.1). Úroveň získaných znalostí byla pak hodnocena pomocí didaktického testu, jemuž byli žáci podrobeni týden po absolvování výuky (test č.2). Statistické zhodnocení získaných výsledků bylo provedeno pomocí programů Excel a Statistica. Pro zjištění průkaznosti rozdílů mezi výsledky žáků obou testovaných skupin bylo použito Studentova t testu.

\section{Didaktický test:}

Hodnocení probíhalo formou didaktického testu, jehož cílem bylo zjistit:

a) stupeň znalostí v oblasti fyziologie fotosyntézy a transpirace (není obsahem tohoto článku);

b) stupeň znalostí environmentálních souvislostí probírané tématiky - funkce stromu v krajině a význam pro člověka.

Sestavování testu, jeho vlastní aplikace i hodnocení bylo prováděno podle obecně respektovaných principů pedagogického výzkumu (např. Chráska, 1999, 2007). 
Srozumitelnost a obtížnost otázek zařazených $\mathrm{v}$ testu byla předem ověřována $v$ pilotním průzkumu se 14 žáky. $V$ návaznosti na výsledky pilotáže byl pak test upraven do finální podoby.

Test obsahoval celkem 14 otázek bodovaných dle obtižnosti a typu otázky rozdílným počtem bodů. Následující analýza se zabývá hodnocením znalostí pouze z oblasti environmentální problematiky. $\mathrm{K}$ tomuto účelu bylo využito následujících otázek $\mathrm{v}$ testu obsažených:

\section{Jaké funkce může mít v přírodě strom?}

(otevřená otázka, max. možný počet bodů 8 , po 1 bodu za každou správnou odpověd)

2. Bez jakého děje, který probíhá také ve stromech, by neexistoval život na Zemi?

\section{a) fotosyntéza b) transpirace c) př́ijem vody d) pohlcování prachových částic}

(uzavřená otázka, možnost výběru ze 4 odpovědí max. počet bodů 0,5 )

\section{Co vše se děje se sluneční energií dopadající na Zemi?}

(otevřená otázka, max. možný počet bodů 4 , po 1 bodu za každou správnou odpověd)

4. Přiřad' živočichy $k$ části stromu, kterou obývají:

\begin{tabular}{|l|c|l|}
\hline sedmihlásek hajní & kořeny stromu & lesní \\
veverka obecná & datel černý \\
včela medonosná & koruna stromu & lýkožrout smrkový \\
dutohlávka sobí & václavka obecná \\
sýkora koňadra & puštík obecný \\
\hline
\end{tabular}

(přiřazení formou spojení čarou, max. možný počet bodů 5 po 0,5 bodu za každou správnou odpověd')

\section{Vysvětli pojem rekreační funkce stromu:}

(otevřená otázka max. počet 1-5 bodů - po 0,5 bodu za každý typ rekreační funkce stromu)

Po absolvování testu proběhla pak se žáky obou testovaných skupin diskuse k výuce.

\section{Výsledky a diskuse:}

První test aplikovaný před provedením výuky neprokázal žádné významné rozdíly v míre spontánních znalostí mezi oběma testovanými skupinami žáků. (obr. č. 1). 
Obr. č. 1: Výsledky testu č. 1 realizovaného před výukou.

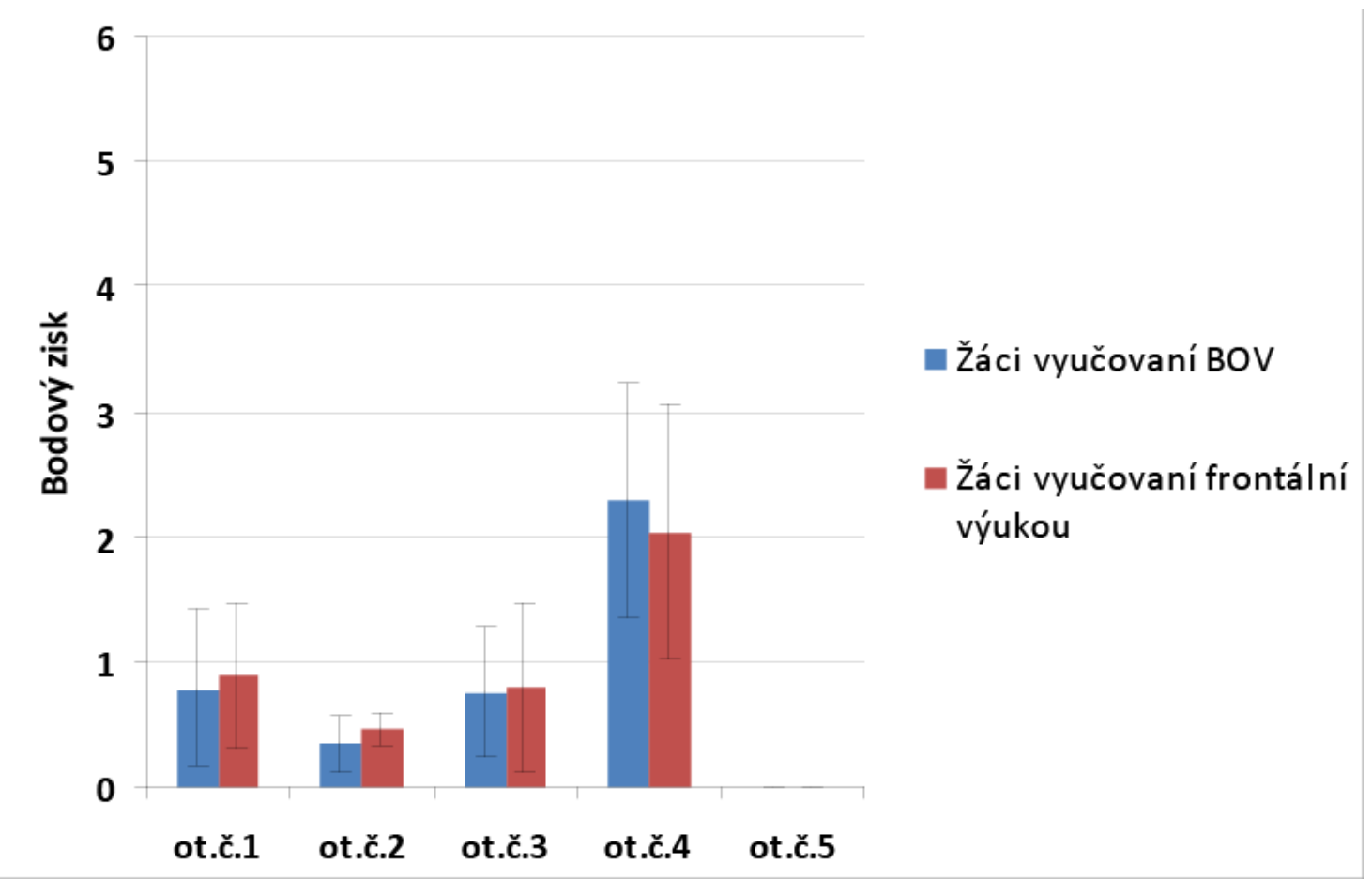

Uvedeny jsou hodnoty průměrného bodového zisku včetně směrodatných odchylek u jednotlivých otázek

Test prokázal nedostatečné spontánní znalosti environmentální problematiky. Významným poznatkem vyplývajícím z testu č. 1 je nulový bodový zisk u všech testovaných žáků $v$ otázce č. 5 . Nikdo z 57 testovaných žáků si nevybavil ani jednu rekreační funkci stromu. Na tomto místě je jistě potřeba se zamyslet nad vhodností formulace a srozumitelností otázky. Pilotní prủzkum však prokázal, že pojem "rekreace" a "rekreační funkce" je žákům srozumitelný. Ani z následné besedy se žáky, kteří test absolvovali, nevyplynulo, že by jim otázka byla nesrozumitelná. Uváděli ale např., že si „nemohli na nic vzpomenout". Tento poznatek tedy svědčí pouze o tom, že žáci si neuvědomují význam stromů v každodenním životě každého člověka.

Vyhodnocení druhého testu po absolvování výuky hovoří ve prospěch badatelsky orientovaného vyučování. Ve 4 z 5 sledovaných otázek dosahovali žáci, kteří absolvovali interaktivní formu badatelsky orientované výuky, lepších výsledků. V otázkách č. 3,4 a 5 byly rozdíly mezi oběma testovanými soubory žáků statisticky průkazné (obr. č. 2). 


\section{Obr. č. 2: Výsledky 2. testu po absolvování výuky.}



Uvedeny jsou hodnoty průměrného bodového zisku včetně směrodatných odchylek u jednotlivých otázek. * značí statisticky významný rozdíl mezi výsledky žáků obou testovaných skupin hodnocený Studentovým t testem na hladině významnosti 0,05.

Pouze $v$ první sledované otázce nebyly zjištěny rozdíly $v$ míre znalostí mezi žáky obou sledovaných skupin. Nečastější chybou u otázky č. 1 bylo to, že žáci si prvotně pod pojmem funkce stromu $v$ prírodě vybavili jeho průmyslové využití (dřevo, papír), nikoli jeho funkce v krajině (např́klad to, že vyrábí kyslík, chladí vzduch, funguje jako větrolam, protiprachová a protihluková bariéra). V následné diskusi se žáky se jako odpověd' na otázku "Co vám nejvíce pomohlo k zodpovězení první otázky?" objevovaly např. tyto odpovědi:

\section{a) žáci, kteří absolvovali BOV:}

„Pomohlo mi, že jsem si vzpomněla na pokus s teploměrem na videu."

"Mně pomohlo to, že jsem na začátku hodiny hádal, jaké funkce by mohl mít strom, a když jsem něco řekl správně, hned se to ukázalo na tabuli."

„Vzpomněl jsem si, jak na tabuli zajíždělo autíčko mezi stromy, a když tam zmizelo, nebylo už slyšet motor."

„Já jsem si vybavil živý plot, který máme doma na zahradě, a přemýšlel jsem, k čemu všemu může sloužit."

\section{b) žáci, kteří absolvovali frontální výuku)}

„Pomohlo mi, když jsme si říkali, že strom je jako př́rodní chladnička a že kdyby nebyly stromy, nebylo by tolik kyslíku".

„Mně pomohlo, když mi spolužáci vyprávěli, co bylo na interaktivní tabuli". 
V otázce č. 2 chybovala jen malá část žáků. Výsledky žáků s BOV výukou byly mírně vyšší, tento rozdíl však nebyl statisticky významný.

V otázkách č. 3 a 4 byly zaznamenány výrazně lepší výsledky u žáků vyučovaných BOV. Obzvláště otázka č. 3 je z hlediska hodnocení prínosu BOV pro environmentální výchovu velmi důležitá. Správná odpověd' na ni totiž vyžadovala u žáků vyučovaných BOV vlastní formulaci závěrů vyvozených ze sledu videosekvencí a animací vycházejících z našeho okolního prostředí, které byly zařazeny do výukového programu. U žáků testovaných BOV byl stupeň znalostí u této otázky výrazně vyšší.

U otázky č. 5 došlo po absolvování výuky k nárůstu znalostí rekreační funkce stromu - významněji však u skupiny BOV.

Z vlastní realizace BOV vyplynul zájem žáků o výuku. 100 \% žáků ve všech třech testovaných tř́́dách se aktivně zapojovalo do výuky. Také $v$ následné diskusi reagovali na položené otázky rychleji než žáci z kontrolní skupiny. Většina žáků testovaných frontální výukou se přiznala, že si prála být ve skupině badatelsky orientované výuky. Jediným negativem výuky bylo, že žáci, kteří se s výukou za pomoci interaktivní tabule setkávali poprvé, byli zpočátku roztěkaní a věnovali svou pozornost spíše funkčnosti tabule samotné než probíranému učivu. Tento problém ale zanikl $v$ podstatě inned po spuštění první motivační videosekvence. $Z$ diskuse se žáky vyplynul zájem jak o badatelsky orientovanou výuku, tak i o práci s interaktivní tabulí. Zajímavým tématem pro další výzkum se tedy jeví zjistit, do jaké míry je motivace žáků zvyšována vlastním fenoménem možnosti práce s interaktivní tabulí a do jaké míry vlastním badatelsky orientovaným pojetím výuky. Spojení obou těchto jevů se v tomto pedagogickém experimentu ukázalo jako pozitivní.

\section{Závěr:}

Studie prokázala vhodnost využití badatelsky orientované výuky pro environmentální výchovu. Výuka byla žáky přijímána velmi pozitivně, podnítila jejich zájem o probíranou tematiku. Záci,kteří absolvovali badatelsky orientovanou výuku s využitím interaktivní tabule, dosahovali v hodnotícím testu většinou lepších výsledků než žáci, kteří absolvovali klasickou výuku frontální, bez uplatnění principủ BOV. Vzhledem k tomu, že se jedná o jednu z prvních aplikací BOV do environmentální výchovy na ZŠ, vyžaduje tato problematika další studie.

\section{Seznam použité literatury}

- Czesaná, V., Matoušková, Z., HavlíčkovÁ, V., Šímová, Z., Kofroňová, O., Lapáček, M., . . . Žáčková, H. (2009). Ročenka konkurenceschopnosti České republiky 2007 - 2008. Analýza. Část - kvalita lidských zdrojů. Praha: Národní observatoř zaměstnání a vzdělání NVF, Centrum výzkumu konkurenceschopnosti české ekonomiky.

- Eastwell, P. (2009). Inquiry learning: Elements of confusion and frustration. The American biology teacher. The American biology teacher, 71(5), 263-264.

- Edelson, D. C., Gordin, D. N., \& Pea, R. D. (1999). Addressing the Challenges of InquiryBased Learning Through Technology and Curriculum Design.Journal of the Learning $\begin{array}{llll}\text { Sciences, 8(3-4), 391-450. } & \text { Retrieved }\end{array}$ http://www.tandfonline.com/doi/abs/10.1080/10508406.1999.9672075 http://dx.doi.org/10.1080/10508406.1999.9672075

- European Commission. Science Education NOW: A Renewed Pedagogy for the Future of Europe (2007). Luxembourg: Office for Officiel Publications of the European Communities. 
- Forbes, C. T., Cory, T., \& Zint, M. (2011). Elementary teachers' beliefs about, perceived competencies for, and reported use of scientific inquiry to promote student learning about and for the environment. Journal of Environmental Education, 42(1), 30-42.

- Hammond, M., Reynolds, L., \& Ingram, J. (2011). How and why do student teachers use ICT. Journal of Computer Assisted Learning, 27(3), 191-203. Retrieved from http://doi.wiley.com/10.1111/j.1365-2729.2010.00389.x http://dx.doi.org/10.1111/j.1365$\underline{2729.2010 .00389 . x}$

- Chráska, M. (1999). Didaktické testy. Př́ručka pro učitele a studenty učitelství. Brno: Paido.

- Chráska, M. (2007). Metody pedagogického výzkumu. Základy kvantitativního výzkumu. Praha: Grada.

- Janoušková, S. . Environmentální výchova v RVP ZV. Metodický portál: Články [online]. . Retrieved from http://clanky.rvp.cz/clanek/c/ZVO/275/ENVIRONMENTALNI-VYCHOVA-V-RVP$\underline{\text { ZV.html }}$

- JanouškovÁ, S., Novák, J., \& Maršák, J. (2008). Trendy ve výuce prírodovědných oborů z evropského pohledu. Acta Facultatis Paedagiogicae Universitatis Trnaviensis, Ser. D, Supplementum, 2(12), 129-132. Retrieved from http://pdfweb.truni.sk/katchem/ZBORNIK 2008/Janouskova Novak Marsak.pdf

- Michaels, S., Shouse, A. W. \& Schweingruber, H. A., (2008). Ready, Set, Science! Putting research to work in K-8 science classrooms. National Research Council. National Academic Press. Washington D.C. . Retrieved from http://www.nap.edu/catalog.php?record id=11882

- Osborne, J., \& Dillon, J. (2008). Science Education in Europe: Critical reflections. . Retrieved from http://www. nuffieldfoundation.org/science-educationeurope

- Papáček, M. (2010) Limity a šance zavádění badatelsky orientovaného vyučování prírodopisu a biologie v České republice. In M. Papáček (Ed.), Didaktika biologie v České republice 2010 a badatelsky orientované vyučování. DiBi, 2010. Sborník příspěvků semináre, 25. a 26. března 2010 (pp. 145-162). : Jihočeská univerzita, České Budějovice.

- Reháková, J. (2011). Strom: Funkce v krajině a význam pro člověka. Diplomová práce. Manuskript. Č. Budějovice: Jihočeská univerzita v Českých Budějovicích, Pedagogická fakulta.

- Stuchlíková, I. . O badatelsky orientovaném vyučování. Didaktika biologie v České republice 2010 a badatelsky orientované vyučování. DiBi, 2010. Sborník příspěvků semináře, 25. a 26. března 2010. České Budějovice: Jihočeská univerzita.

- Ye, Z. N., Barker, S., Rowell, P., Reyes, P., Zhou, J. Z., Jenkins, F., . . . Fuentes, E. L. (2008). Globalization of science inquiry and education for sustainable development. MBE 2008: Asia - Pacific conference on mind brain and education, 108-112.

\section{Poděkování:}

Tento př́spěvek vznikl s podporou projektu GA JU č.065/2010/S. Autorky děkují vyučujícím zúčastněných škol za ochotu a spolupráci na výzkumu.

Mgr. Renata Ryplová, Dr., Jarmila Reháková

Autorky článku v současné době působí na Katedře biologie Pedagogické fakulty Jihočeské univerzity v Českých Budějovicích.

Kontakt: Jeronýmova 10, 37115 České Budějovice, E mail: ryplova@pf.jcu.cz 
Časopis Envigogika vydává Centrum pro otázky životního prostředí UK. Vývoj časopisu je podpořen projektem OP VK Mezioborová sít udržitelného rozvoje.

Více najdete na internetových stránkách projektu mosur.czp.cuni.cz
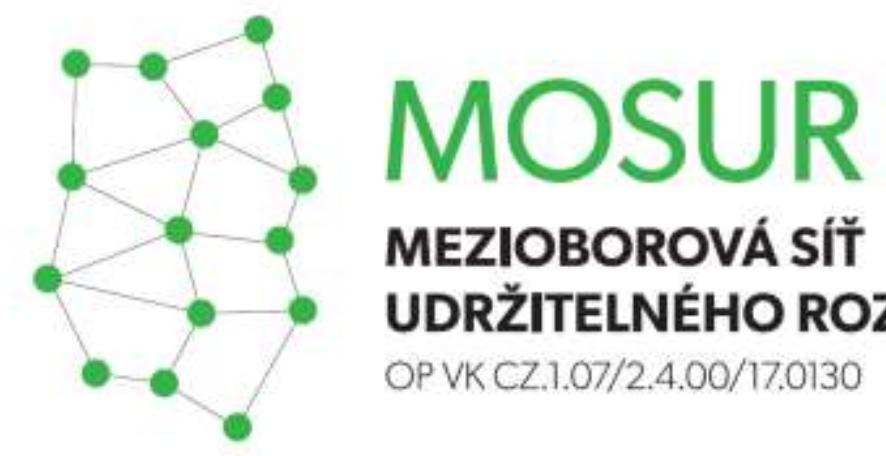

\section{MEZIOBOROVÁ SÍT} UDRŽITELNÉHO ROZVOJE

OP VK CZ.1.07/2.4.00/17.0130
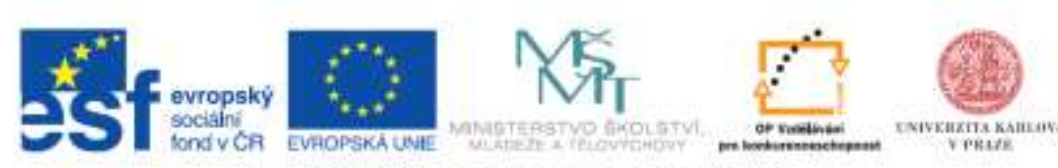

INVESTICE DO ROZVOUE VZDELAVANI 